\title{
Effect of season on structural composition of drake testes and daily spermatozoa production as determined by quantitative testicular histology
}

\author{
GODWIN CHIDOZIE OKPE, ANIETIE FRANCIS UDOUMOH
}

\begin{abstract}
Department of Veterinary Anatomy, Faculty of Veterinary Medicine, University of Nigeria, Nsukka 410001, Nigeria
\end{abstract}
\section{Okpe G. C., Udoumoh A. F.}

Effect of season on structural composition of drake testes and daily spermatozoa production as determined by quantitative testicular histology

\section{Summary}

Seasonal effects on the structural features of drake testes and daily spermatozoa production were investigated by a light microscopy technique, as well as morphometric and quantitative histological procedures. The present study is aimed at understanding the effects of different seasons on the reproductive potential of drakes. The results showed that the volume of the testes occupied by seminiferous tubules was similar $(P>0.05)$ in all the seasons studied. However, the relative percentage of the primary spermatocytes, spermatids, spermatozoa, epithelial height, lumen diameter, and Leydig cells were significantly higher $(p<0.05)$ during the early and late rainy seasons compared to the early and late dry seasons. The daily sperm production per testis in the early rainy season, late rainy season, early dry season, and late dry season were $0.86 \times 10^{9} \pm 1.30,0.84 \times 10^{9} \pm 1.20$, $0.54 \times 10^{9} \pm 1.13$ and $0.52 \times 10^{9} \pm 1.17$, respectively. The daily sperm productions per testis and per gram of testes were significantly higher $(p<0.05)$ during the early rainy season compared to the early and late dry seasons, respectively. All the micrographs examined, showed evidence of normal spermatogenesis throughout the year. The findings in the present study indicate that drakes in the tropical environment (south-eastern Nigeria) are capable of breeding throughout the year; however, sperm production efficiency is optimal during the early rainy season.

Keywords: drake, season, sperm production, testes morphometry

Ducks occur in all continents of the world except Antarctica (24). Duck populations have been depleted due to habitat loss and pollution (17). Presently duck conservation is a priority for governments and private agencies. Although ducks are known worldwide, their economic importance and contribution to food security varies between countries. It has been reported that meats and eggs of duck have a high nutritional value, as they contain an optimal composition of essential amino acids and a high percentage of polyunsaturated fatty acids with a favorable ratio of omega- 6 to omega-3 fatty acids (8). Despite the superior quality of duck eggs and meat, interest in duck production in Nigeria is negligible. Most probably, the reduced interest in duck production forced researchers to shift their attention to studies involving other avian species. To stimulate interest in duck production, extensive knowledge of the duck's reproductive potential is required. It is therefore essential to search for baseline information on the anatomy and physiology of the reproductive organs of ducks. In temperate regions, the duck has been described as a seasonal breeder, breeding only during the spring (8). In evaluating the spermatogenic efficiency of males reared under varying environmental conditions, it is essential to determine their sperm production potential (19). The environment, encompassing climatic, nutritional, and biotic factors, plays a major role in synchronizing reproductive rhythms (27).

Quantitative histology has been used in determining daily sperm production in boars (10), rabbits (3), rats (13), goats (6), and domestic fowl (19). Information on possible seasonal variation in the breeding potential of ducks in the tropical environment is lacking. The present study is aimed at investigating the effects of different seasons on the reproductive potential of drakes with the use of both descriptive and quantitative histology in the Nigerian tropical environment. Information from such a study may be helpful in the proper and profitable management of duck production. 


\section{Material and methods}

Animals. Twenty adult (four-month-old) male ducks were used for this study. The study was carried out in Nsukka, south-eastern Nigeria. Nsukka is located on latitude $6.85783 \mathrm{~N}$ and longitude $7.39577 \mathrm{E}$. The period of the study covered the two main seasons of the year, the rainy season (April to September) and the dry season (October to March). The study period was subdivided into the early rainy season (April, May and June), the late rainy season (July, August, September), the early dry season (October, November, December) and the late dry season (January, February, March). The ducks were reared freely in the poultry house of a veterinary teaching farm, Faculty of Veterinary Medicine, University of Nigeria, Nsukka. They were fed a standard broiler ration and given water ad-libitum. At the onset of the study, the birds were individually weighed with a Metler balance. Each duck was then killed with an overdose of chloroform anaesthesia (Sigma, USA). Immediately after slaughter, both testes were dissected out, trimmed of adhering tissues, and weighed. The length, width, and thickness of the testes were measured with a Vernier caliper. The volume of each testis was determined by the water displacement (flotation) method (21).

Histological procedures. Small pieces of testis samples were taken from the right and left testes of each duck and fixed in Bouin's fluid for 24 hours, then dehydrated in ascending concentrations of ethanol, cleared in xylene, and embedded in paraffin. The samples were cut with a rotatory microtome into $6 \mu \mathrm{m}$ thick sections, which were stained with haematoxylin and eosin (H\&E). The sections were examined with a Leica light microscope, and findings were captured with a digital opticam camera attached to a computer.

Tubular measurements and histological evaluation. The tubular diameter, luminal diameter, and heights of the seminiferous epithelium of the seminiferous tubules, as well as the diameter of round spermatid nuclei were measured with a standardized ocular micrometer. The tubular and luminal diameters of the tubules were measured randomly by choosing 30 round or nearly round tubular profiles per animal, irrespective of the cycle of the seminiferous epithelium. The height of the seminiferous epithelium was obtained using the same tubules that were used to determine the tubular diameter (22).

Determination of volume densities of testes components. The volume percentages of the testes components such as the capsule, seminiferous tubule, blood vessel, lymphatic vessel, spermatogonia, primary spermatocyte, secondary spermatocytes, spermatids, spermatozoa, Sertoli cells, and Leydig cells were determined as described by Leal et al., using a 25-point ocular graticule (16). All structures under each cross section (hit) were recorded.

The length of the seminiferous tubules was determined by the formula

Testis vol. $\times$ vol. density

Tubular length per testis $=\frac{\text { of the seminiferous tubule }}{\pi \mathrm{r}^{2}}$,

where $r=$ radius of the seminiferous tubule (26).
Determination of daily sperm production (DSP)

Daily sperm production (DSP) per testis was determined by the quantitative histology (histometric) method (21).

$\times$ Volume $\%$ round spermatid nuclei

DSP per testis $=\frac{\text { in the testis }}{\text { Average volume per round spermatid }}$ nucleus $\times$ Life-span of round spermatids in days

Corrected testes volume (CTV) is determined by the formula

$$
\text { CTV }=\frac{\begin{array}{c}
\text { Gross testes weight } \\
\text { Tunica albuginea weight }
\end{array}}{\text { Testes density }} \times \text { Shrinkage }
$$

The volume of round spermatids was obtained by the method of Swierstra, whereas tissue shrinkage was determined using Abercrombie's correction factor $(1,23)$.

The efficiency of sperm production was determined by dividing the daily sperm production by the testis parenchyma weight.

Statistical analysis. Data were subjected to one-way analyses of variance (ANOVA). Differences among groups were determined by Tukey's multiple comparison tests. Differences among means were considered statistically significant at $\mathrm{P}<0.05$.

\section{Results and discussion}

The mean body weights of the drakes were not significantly different during the periods studied. The gross dimensions of the testes are shown in Tab. 1. There were no significant $(p>0.05)$ seasonal variations in the paired tunica albuginea weights, length, width and density of the testes. However, the paired testes weight, parenchymal weights, and testes volume were significantly higher $(\mathrm{p}<0.05)$ during the early and late rainy seasons compared to the early and late dry seasons, respectively. Although the absolute values of these parameters were higher during the early rainy season, statistically significant differences were not observed between the early and late rainy seasons. Similarly, significant differences were not found between the values for the early dry season and those for the late dry season. The volume densities of the components of the testes are shown in Tab. 2. The volume of the testes occupied by seminiferous tubules was similar $(\mathrm{P}>0.05)$ in all the seasons studied. Similarly, the volume densities of blood vessels, lymphatics, spermatogonia, and Sertoli cells were not significantly $(p>0.05)$ different across the seasons. However, the relative percentage of primary spermatocytes, spermatids, spermatozoa, epithelia height, lumen diameter, and Leydig cells were significantly higher $(\mathrm{p}<0.05)$ during the early and late rainy seasons compared to the early and late dry seasons, respectively. The volume densities of these components of the testes were similar $(p>0.05)$ during the two rainy seasons. Similarities of 
Tab. 1. Biometric data for the testes of adult drakes collected during different annual seasons (Mean \pm SEM)

\begin{tabular}{|l|c|c|c|c|}
\hline \multicolumn{1}{|c|}{ Dimensions } & $\begin{array}{c}\text { Early rainy season } \\
\text { (April-June) }\end{array}$ & $\begin{array}{c}\text { Late rainy season } \\
\text { (July-September) }\end{array}$ & $\begin{array}{c}\text { Early dry season } \\
\text { (October-December) }\end{array}$ & $\begin{array}{c}\text { Late dry season } \\
\text { (January-March) }\end{array}$ \\
\hline Body weight (kg) & $1.72 \pm 1.24^{\mathrm{a}}$ & $1.74 \pm 0.74^{\mathrm{a}}$ & $1.69 \pm 0.44^{\mathrm{b}}$ & $1.73 \pm 0.52^{\mathrm{b}}$ \\
\hline Paired testes weight (g) & $10.10 \pm 0.34^{\mathrm{a}}$ & $10.05 \pm 0.17^{\mathrm{a}}$ & $7.32 \pm 0.19^{\mathrm{b}}$ & $7.25 \pm 0.25^{\mathrm{b}}$ \\
\hline Paired tunica albuginea weight (g) & $0.80 \pm 0.41^{\mathrm{a}}$ & $0.76 \pm 1.00^{\mathrm{a}}$ & $0.85 \pm 0.37^{\mathrm{a}}$ & $0.82 \pm 0.16^{\mathrm{a}}$ \\
\hline Paired parenchyma weight (g) & $9.30 \pm 0.41^{\mathrm{a}}$ & $9.29 \pm 0.23^{\mathrm{a}}$ & $6.37 \pm 0.12^{\mathrm{b}}$ & $6.43 \pm 0.67^{\mathrm{b}}$ \\
\hline Gonado-somatic index (\%) & $0.58 \pm 3.12^{\mathrm{a}}$ & $0.57 \pm 2.12^{\mathrm{a}}$ & $0.43 \pm 0.73^{\mathrm{b}}$ & $0.41 \pm 0.16^{\mathrm{b}}$ \\
\hline Testes length (cm) & $1.92 \pm 0.12^{\mathrm{a}}$ & $1.87 \pm 0.73^{\mathrm{a}}$ & $1.84 \pm 0.47^{\mathrm{a}}$ & $1.86 \pm 0.10^{\mathrm{a}}$ \\
\hline Testes width (cm) & $0.98 \pm 0.31^{\mathrm{a}}$ & $0.94 \pm 0.08^{\mathrm{a}}$ & $0.95 \pm 0.32^{\mathrm{a}}$ & $0.93 \pm 0.77^{\mathrm{a}}$ \\
\hline Paired testes volume $\left(\mathrm{cm}^{3}\right)$ & $10.05 \pm 0.42^{\mathrm{a}}$ & $9.68 \pm 0.21^{\mathrm{a}}$ & $7.03 \pm 0.19^{\mathrm{b}}$ & $7.00 \pm 0.78^{\mathrm{b}}$ \\
\hline Density of testes $\mathrm{g} / \mathrm{cm}^{3}$ & $1.00 \pm 0.23^{\mathrm{a}}$ & $1.03 \pm 0.06^{\mathrm{a}}$ & $0.95 \pm 0.13^{\mathrm{a}}$ & $0.92 \pm 0.45^{\mathrm{a}}$ \\
\hline
\end{tabular}

Explanation: $\mathrm{a}, \mathrm{b}$ - different superscripts $\left({ }^{\mathrm{a}, \mathrm{b}}\right)$ within a row indicate statistically significant differences at $\mathrm{p} \leq 0.05$.

Tab. 2. Morphometric data for testes showing volume densities (\%) of testes components in adult drakes collected during different annual seasons

\begin{tabular}{|l|c|c|c|c|}
\hline \multicolumn{1}{|c|}{ Components of testes } & $\begin{array}{c}\text { Early rainy season } \\
\text { (April-June) }\end{array}$ & $\begin{array}{c}\text { Late rainy season } \\
\text { (July-September) }\end{array}$ & $\begin{array}{c}\text { Early dry season } \\
\text { (October-December) }\end{array}$ & $\begin{array}{c}\text { Late dry season } \\
\text { (January-March) }\end{array}$ \\
\hline Capsule & $4.30 \pm 0.11^{\mathrm{a}}$ & $4.45 \pm 0.20^{\mathrm{a}}$ & $4.35 \pm 0.33^{\mathrm{a}}$ & $4.67 \pm 0.67^{\mathrm{a}}$ \\
\hline Seminiferous tubules & $87.31 \pm 0.16^{\mathrm{a}}$ & $86.00 \pm 0.27^{\mathrm{a}}$ & $85.92 \pm 0.97^{\mathrm{a}}$ & $85.00 \pm 0.34^{\mathrm{a}}$ \\
\hline Blood vessels & $1.30 \pm 0.24^{\mathrm{a}}$ & $1.19 \pm 0.14^{\mathrm{a}}$ & $1.22 \pm 0.63^{\mathrm{a}}$ & $1.14 \pm 0.75^{\mathrm{a}}$ \\
\hline Lymphatics & $0.50 \pm 0.13$ & $0.62 \pm 0.09$ & $0.32 \pm 0.23$ & $0.43 \pm 0.29$ \\
\hline Spermatogonia & $8.73 \pm 0.77^{\mathrm{a}}$ & $8.94 \pm 0.74^{\mathrm{a}}$ & $8.30 \pm 0.45^{\mathrm{a}}$ & $8.75 \pm 0.81^{\mathrm{a}}$ \\
\hline Primary spermatocytes & $20.67 \pm 1.22^{\mathrm{a}}$ & $21.23 \pm 0.89^{\mathrm{a}}$ & $13.12 \pm 0.61^{\mathrm{b}}$ & $12.90 \pm 0.66^{\mathrm{b}}$ \\
\hline Spermatids & $22.34 \pm 1.34^{\mathrm{a}}$ & $21.89 \pm 0.87^{\mathrm{a}}$ & $10.05 \pm 0.91^{\mathrm{b}}$ & $9.80 \pm 0.27^{\mathrm{b}}$ \\
\hline Spermatozoa & $10.32 \pm 0.74^{\mathrm{a}}$ & $11.51 \pm 0.92^{\mathrm{a}}$ & $6.20 \pm 0.27^{\mathrm{b}}$ & $6.00 \pm 0.73^{\mathrm{b}}$ \\
\hline Sertoli cells & $4.38 \pm 1.44^{\mathrm{a}}$ & $4.27 \pm 2.10^{\mathrm{a}}$ & $4.21 \pm 0.84^{\mathrm{a}}$ & $4.23 \pm 0.42^{\mathrm{a}}$ \\
\hline Lumen & $13.26 \pm 0.67^{\mathrm{a}}$ & $12.74 \pm 0.77^{\mathrm{a}}$ & $8.76 \pm 0.05^{\mathrm{b}}$ & $8.84 \pm 0.45^{\mathrm{b}}$ \\
\hline Leydig cells & $1.32 \pm 0.56^{\mathrm{a}}$ & $1.25 \pm 0.42^{\mathrm{a}}$ & $0.85 \pm 0.21^{\mathrm{b}}$ & $0.91 \pm 0.34^{\mathrm{b}}$ \\
\hline
\end{tabular}

Explanation: $\mathrm{a}, \mathrm{b}-$ as in Tab. 1.

Tab. 3. Morphometric data for the seminiferous tubules and daily sperm production in the testes of adult drakes collected during different annual seasons (Mean \pm SEM)

\begin{tabular}{|l|c|r|r|r|}
\hline \multicolumn{1}{|c|}{ Seminiferous tubule components } & $\begin{array}{c}\text { Early rainy season } \\
\text { (April-June) }\end{array}$ & $\begin{array}{c}\text { Late rainy season } \\
\text { (July-September) }\end{array}$ & $\begin{array}{c}\text { Early dry season } \\
\text { (October-December) }\end{array}$ & $\begin{array}{c}\text { Late dry season } \\
\text { (January-March) }\end{array}$ \\
\hline Epithelium height $(\mu \mathrm{m})$ & $100 \pm 2.90^{\mathrm{a}}$ & $98.50 \pm 0.16^{\mathrm{a}}$ & $72.91 \pm 0.43^{\mathrm{b}}$ & $71.23 \pm 0.13^{\mathrm{b}}$ \\
Tubule diameter $(\mu \mathrm{m})$ & $230 \pm 1.87^{\mathrm{a}}$ & $229 \pm 3.80^{\mathrm{a}}$ & $165.82 \pm 1.83^{\mathrm{b}}$ & $162.46 \pm 1.03^{\mathrm{b}}$ \\
\hline Lumen diameter $(\mu \mathrm{m})$ & $34.01 \pm 0.97^{\mathrm{a}}$ & $32.45 \pm 0.86^{\mathrm{a}}$ & $20.31 \pm 0.19^{\mathrm{b}}$ & $20.03 \pm 0.25^{\mathrm{b}}$ \\
\hline Tubule length $(\mathrm{m})$ & $142.05 \pm 2.73^{\mathrm{a}}$ & $139.80 \pm 3.56^{\mathrm{a}}$ & $101.09 \pm 1.11^{\mathrm{b}}$ & $100.91 \pm 1.73^{\mathrm{b}}$ \\
\hline Daily sperm production/testis $\left(10^{\mathrm{g}}\right)$ & $0.86 \pm 1.30^{\mathrm{a}}$ & $0.84 \pm 1.20^{\mathrm{a}}$ & $0.54 \pm 1.13^{\mathrm{b}}$ & $0.52 \pm 1.17^{\mathrm{b}}$ \\
\hline Daily sperm production/g of testis $\left(10^{6}\right)$ & $85.57 \pm 0.11^{\mathrm{a}}$ & $84.84 \pm 0.21^{\mathrm{a}}$ & $73.97 \pm 0.67^{\mathrm{b}}$ & $71.72 \pm 0.27^{\mathrm{b}}$ \\
\hline
\end{tabular}

Explanation: $\mathrm{a}, \mathrm{b}$ - as in Tab. 1.

these values were also observed during the early and late dry seasons. The dimensions of the components of the seminiferous tubules and daily sperm production are presented in Tab. 3. The height of the seminiferous epithelium, as well as the diameter and length of the seminiferous tubules, was significantly higher $(p<0.05)$ during the early and late rainy seasons compared to the early and late dry seasons, respectively. Similarly, the daily sperm production per testis and daily sperm production per gram of testes were signifi- cantly higher during the early rainy season compared to the early and late dry seasons, respectively. There was no significant difference in daily sperm production during the early and late dry seasons.

Histologically, the seminiferous tubules were loosely surrounded by a compact layer of myofibroblasts and connective tissue. Adjacent to this layer was a loose connective tissue, the interstitium, which contained Leydig cells arranged singly or in a few scattered clusters of 2 to 3 cells per cluster (Fig. 1). Blood 


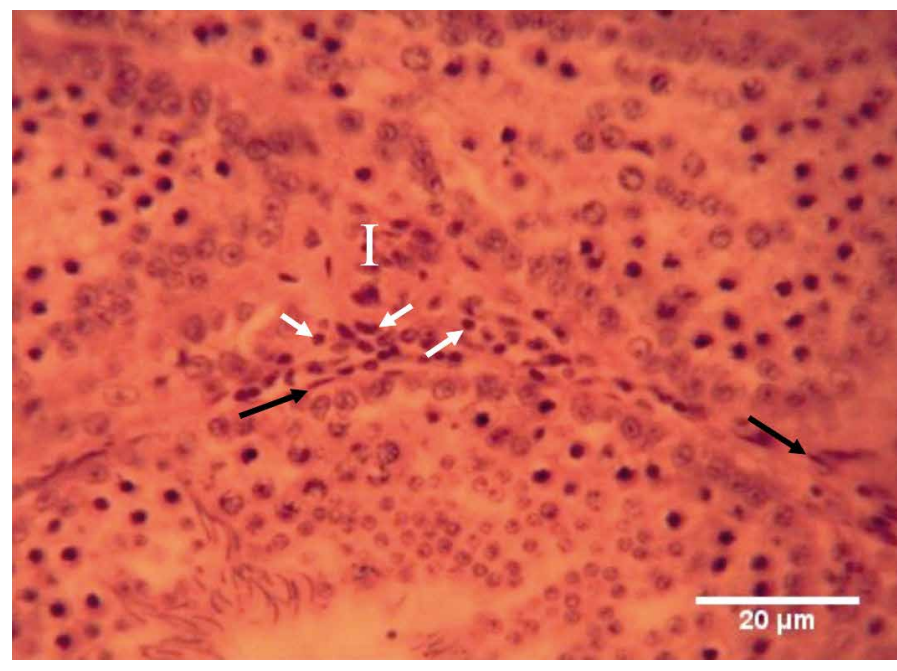

Fig. 1. A testis of an adult drake during the early dry season, showing a cluster of Leydig's cells (white arrow) in the interstitium (I), myofibroblasts (black arrows), and active seminiferous epithelium H\&E stain, $\times 400$

vessels and lymphatics were sparsely distributed in the interstitium (Fig. 2). The stratified seminiferous epithelium consisted of 5 to 6 cell layers. These cell layers were composed of germ cells, such as spermatogonia, primary and secondary spermatocytes, round spermatids, elongated spermatids, mature spermatozoa, and Sertoli cells (Figs. 1, 2 and 3). The seminiferous epithelium was in different stages of the seminiferous epithelial cycle. Two types of cellular associations were often observed in one seminiferous tubule section. Cytoplasmic processes of Sertoli cells divided the seminiferous epithelium into two compartments, the basal and luminal compartments (Fig. 3). The basal compartment housed the spermatogonia, most of the primary spermatocytes and the nuclei of Sertoli cells,

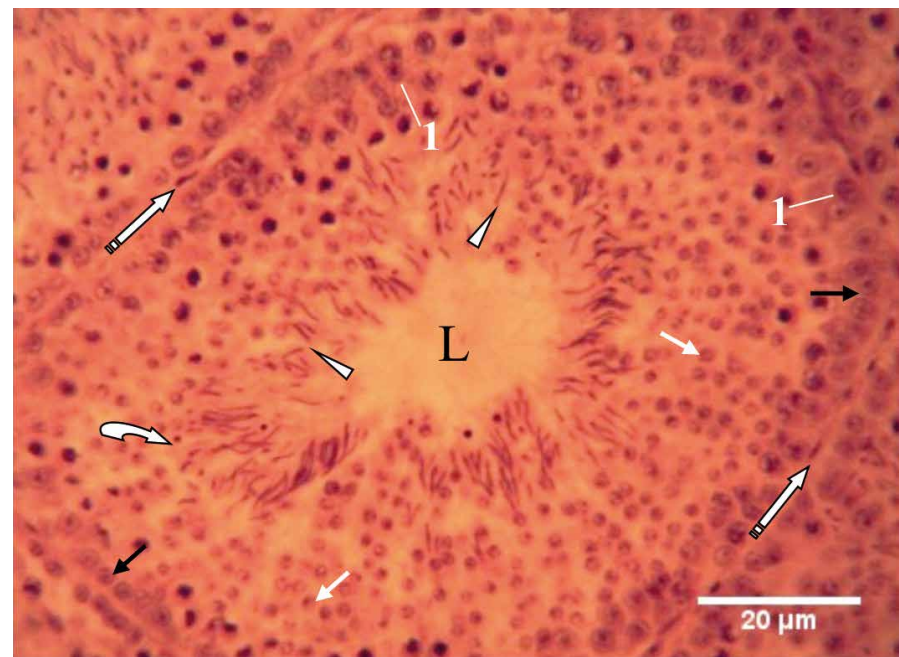

Fig. 3. The profile of a seminiferous tubule of an adult drake during the early rainy season showing spermatogonia (black arrow), spermatocytes (white arrow), round spermatids (curved arrow), elongated spermatids (arrow head), and the tubular lumen (L). Note the Sertoli cell nuclei (1), lying close to the basal lamina. A layer of myoid cells (segmented arrow) is located in a loose connective tissue surrounding the seminiferous tubule. H\&E stain, $\times 400$

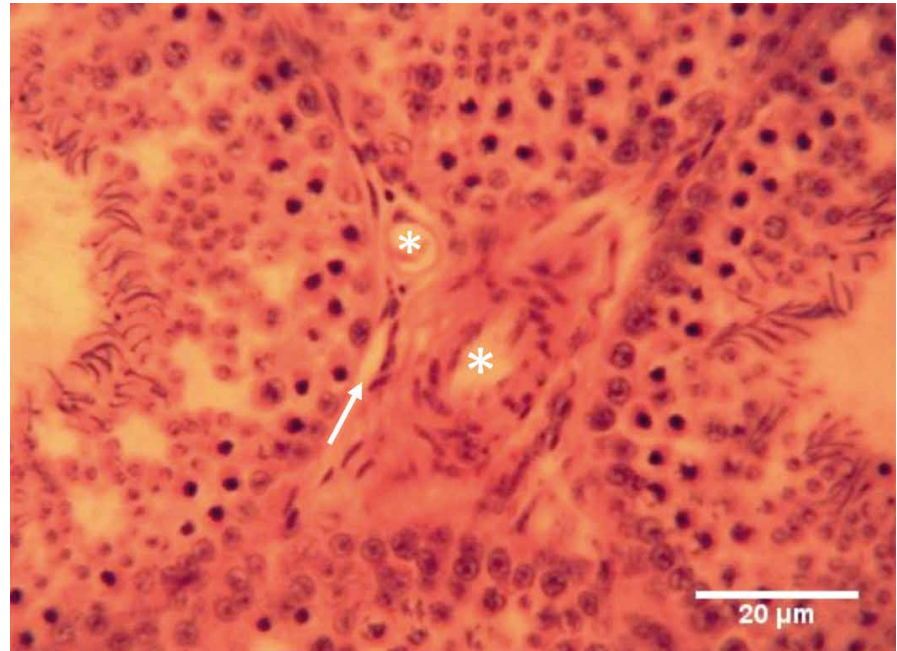

Fig. 2. A testis of an adult drake during the late rainy season showing blood vessels (asterisks) and a lymphatic (arrow) in the interstitium. H\&E stain, $\times 400$

while the luminal compartment contained the more advanced spermatocytes, secondary spermatocytes, round and elongated spermatids, and mature spermatozoa. Numerous residual bodies were observed in the seminiferous tubule lumen.

In the present study, the gonadosomatic indices recorded during the rainy seasons were significantly higher than those of the dry seasons. It is most probable that drakes posses superior spermatogenic efficiency during the rainy season, especially in the early rainy season. In comparison with those of other avian species, the gonadosomatic indices of drakes appear to be low. A gonadosomatic index of $1.1 \%$ was reported in chicken (18), 3.68\% in Japanese quail (15), and 1.58\% in red billed quelea (7). The low gonadosomatic index suggests that drakes have a comparatively small potential for sperm production. This proposition is based on earlier reports that a positive correlation exists between testicular weight and sperm production $(7,16)$.

The dimensions of drake testes (length and width) were similar across the different annual seasons studied. These dimensions were similar to those of guinea fowl testes (2) but different from the values reported earlier for domestic chicken $(5,14,18)$. The differences most probably resulted from possible size differences and genotypic traits.

The dimensions and volume densities of seminiferous tubule tissues were higher during the rainy season compared to the dry season values. These values were highest during the early rainy season, and lowest during the late dry season. These findings suggest that drakes possess the highest potential for sperm production during the early rainy season and the lowest potential during the late dry season. The proposition is based on earlier reports that the relative mass of seminiferous tubule tissues determines the quantum of space devoted to sperm production, and thus there is a positive correlation between the proportion of seminiferous tubular 
tissues and sperm production $(11,12)$. This proposition is further supported by the findings in the present study that the daily sperm production was highest in the early rainy season and lowest in the late dry season. The increase in the parameters of the seminiferous tubule tissues and daily sperm production probably resulted from enhanced testosterone secretion and Sertoli cell efficiency due to increases observed in the relative volume densities of Leydig cells and lumen diameter, respectively. Testosterone plays a vital role in the maintenance of spermatogenesis by enhancing cell division and minimizing apoptosis. Similarly, the size of the seminiferous tubule lumen is determined by the volume of seminiferous tubule fluid and the effectiveness of blood-testis barrier (25).

The dimensions of the seminiferous tubule tissues in all the seasons studied were similar to the values reported for guinea fowl $(2)$, chicken $(9,18)$, and partridge (4). However, these values were smaller than those for white leghorn (20). The differences could be ascribed to the breed and sizes of birds used for the study and to climatic factors.

All the micrographs examined, showed evidence of normal spermatogenesis during different annual seasons. This finding demonstrates that drakes in a tropical environment such as south-eastern Nigeria are capable of breeding throughout the year. However, the peak sperm production probably takes place during the early rainy season. This is unlike drakes found in temperate regions, which are seasonal breeders and can breed only during the spring.

\section{References}

1. Abercrombie M.: Estimation of nuclear population from microtome sections Anat. Rec. 1946, 94, 239-247.

2. Ali M. Z., Qureshi A. S., Rehan S., Akbar S. Z., Manzoor A.: Seasonal variations in histomorphology of testes and bursa, immune parameters and serum testosterone concentration in male guinea fowl (Numida meleagris). Pak. Vet. J. 2015, 35, 88-92

3. Amann R. P.: The male rabbit. IV. Quantitative testicular histology and comparisons between daily sperm production as determined histologically and daily sperm output. Fertil. Steril. 1970, 21, 662-672.

4. Baraldi-Artoni S. M., Bottino F., Oliveira D., Sobue Franzo V., Amoroso L., Orsi A. M., Cruz C.: Morphometric study of Rynchotus rufescens testis throughout the year. Braz. J. Biol. 2007, 67, 363-367.

5. Bezuidenhout A. J.: Veterinary anatomy study and dissection guide. $4^{\text {th }}$ Edition, Saunders W. B., Philadelphia 1999.

6. Bitto I. I., Egbunike G. N.: Seasonal variations in sperm production, gonadal and extragonadal sperm reserves in pubertal West African dwarf bucks in their native tropical environment. Livest. Res. Rural Dev. 2006, 18, 134-134.

7. Calhim S., Birkhead T. R.: Intraspecific variation in testis asymmetry in birds: evidence for naturally occurring compensation. Proc. R. Soc. B. 2009, 267, 2279-2284.

8. Carboneras C.: Family Anatidae (ducks, geese and swans), [in:] del Hoyo J., Elliott A, Sargatal J. (ed.): Handbook of Birds of the World. Vol. 1: Ostrich to Ducks. Lynx Edicions, Barcelona 1992, p. 536-629.

9. Castillo A., Marzoni M., Pirone A., Romboli I.: Histological observations in testes of hybrids of Gallus gallus $\times$ Phasianuns colchicus. Avian Biol. Res. 2012, 5, 1-10.

10. Egbunike G. N., Holtz W., Smidt D.: Reproductive capacity of German Landrance boars: II Sperm production rates as determined by quantitative testicular histology and from gonadal sperm reserves. Reprod. Dom. Anim. 1975, 4, 184-187.

11. França L. R., Russell L. D., Cummins J. M.: Is human spermatogenesis uniquely poor? Ann. Rev. Biomed. Sci. 2002, 4, 19-40.
12. Hess R., França L. R.: History of the sertoli cell discovery, [in:] Griswold M., Skinner M. (ed.): Sertoli Cell Biology. Academic Press, New York 2005.

13. Johnson L., Petty C. S., Neaves W. B.: The relationship of biopsy evaluations and testicular measurements to over-all daily sperm production in human testes. Fertil. Steril. 1980, 34, 36-40.

14. $\operatorname{King}$ A. S.: Aves urinogenital system, the male genital organs, [in:] Getty R. (ed.): Sisson and Grossman's the Anatomy of the Domestic Animals. Saunders W. B., New York 1975, 1927-1935.

15. Lanna L. L., Soares F. A., Santos T. M., Oliveira J. N., Marques Júnior A. P. Gonadosomatic index and correlations between testicular dimensions and weight in Japanese quail (Coturnix coturnix japonica) at 60 days old. Arq. Bras. Med. Vet. Zootec. 2013, 65, 955-960.

16. Leal M. C., Becker-Silva S. C., Chiarini Garcia H., Franca L. R.: Sertoli cell efficiency and daily sperm production in goats (Capra hircus). Anim. Prod. 2004, 1, 122-128.

17. Livezey $B$. C.: A phylogenetic analysis of recent anseriform genera using morphological characters. Auk. 1986, 103, 737-754.

18. Okpe G. C., Nwatu U., Anya K.: Morphometric study of the testes of the Nigerian local breed of chicken. Anim. Res. Int. 2010, 7, 1163-1168.

19. Orlu E. E., Egbunike G. N.: Daily sperm production of the domestic fowl (Gallus domesticus) as determined by quantitative testicular histology and homogenate methods. Pak. J. Biol. Sci. 2009, 12, 1359-1364.

20. Parker J. E., McKenzie F. F., Kempster H. L.: Development of the testes and combs of White Leghorn and New Hampshire cockerels. Poult. Sci. 1942, 21, $35-44$.

21. Scherile $W$ : A simple method for volumetry of organs in quantitative sterology. Mikroskopie Mikroskopite 1970, 26, 57-60.

22. Segatelli T. M., Franca L. R., Inheiro F. P., Alemida C. C. D., Martinez M., Martinez F. E.: Spermatogenic cycle length and spermatogenic efficiency in the Gerbil (Meriones unguiculatus). J. Androl. 2004, 25, 872-880.

23. Swierstra E. E.: Sperm production of boars as mentioned from epididymal sperm reserves and quantitative testicular histology. J. Reprod. Fertil. 1971, 27, 91-99.

24. Tellkamp M. P.: Ducks, geese, and swans (Anatidae), [in:] Grzimek B., Thoney D. A., Schlager N., Trumpey J. E., Hutchins M.: Grzimek's Animal Life Encyclopedia. Thomson-Gale, Detroit 2004

25. Tindall D. J., Vitale R., Means A. R.: Androgen binding protein as a biochemical marker of formation of the blood-testis barrier. Endocrinol. 1975, 97, 636-648.

26. William R. B.: Environmental factors affecting reproduction and development in ascidians and other protochordates. Can. J. Zool. 2005, 83, 51-61.

Corresponding author: Okpe, Godwin Chidozie, Department of Veterinary Anatomy, Faculty of Veterinary Medicine, University of Nigeria, Nsukka 410001, Nigeria; e-mail: godwin.okpe@unn.edu.ng 